\title{
Effect of Organic Manures and Bio-Fertilizers on Floral and Commercial Yield Characters of Strawberry (Fragaria $\times$ ananassa Duch.) cv. Chandler
}

\author{
Aman Srivastav*, Rajaneesh Singh, Hari Baksh, Bijendra K. Singh, Raj pandey, \\ Vishal Kumar Pal and Lawlesh Kumar Maurya
}

Department of Horticulture, TilakDhari Post Graduate College, Jaunpur(U.P.) - 222 002, India

*Corresponding author

\begin{tabular}{|c|}
\hline Keywords \\
\hline $\begin{array}{l}\text { Vermicompost, } \\
\text { Organic manure, } \\
\text { Azotobacter, } \\
\text { Benefit cost ratio, } \\
\text { Net income }\end{array}$ \\
\hline Article Info \\
\hline $\begin{array}{l}\text { Accepted: } \\
\text { 04 January } 2019 \\
\text { Available Online: } \\
\text { 10 February } 2019\end{array}$ \\
\hline
\end{tabular}

\section{A B S T R A C T}

A field study was conducted on the Experimental Unit, Department of Horticulture, Tilak Dhari Post Graduate College, Jaunpur during 2017-18 to study the effect of organic manure and bio-fertilizers on floral and commercial yield characters of strawberry (Fragaria $\times$ ananassa Duch.) cv. Chandler. The runners of strawberry were transplanted in the last week of October with a spacing of $40 \times 40 \mathrm{~cm}$. The experiment was laid out in Randomized Block Design with ten treatments replicated thrice. Maximum number of runners/plant (6.77) and maximum number of crowns/plant (5.16) were reported in treatment Vermicompost + Azotobacter + PSB, while minimum number of runners/plant (2.87) and crowns/plant (2.39) were recorded in control (untreated plants). Minimum days to produce first flower (50.99 days) was recorded in treatment FYM + Vermicompost + Poultry manure + Azotobacter + PSB, while maximum days to produce first flower (60.79 days) was recorded in control (untreated plants). Duration of harvesting (63.75 days), number of flowers/plant (59.91) and number of fruit set/plant (49.60) were recorded highest in treatment FYM + Vermicompost + Poultry manure + Azotobacter+ PSB. Fruit set percentage/plant $(84.05 \%)$ were recorded highest in treatment Vermicompost. Days to fruit set (6.47 days) was recorded minimum in treatment FYM + Vermicompost+ Poultry manure + Azotobacter + PSB, while all floral characters were found minimum in control. Maximum yield/plant $(290.56 \mathrm{~g})$, maximum yield/plot $(2.90 \mathrm{~kg})$ and maximum yield/ha (145.26 qt) was recorded in treatment Vermicompost + Azotobacter + PSB while minimum yield was found in control. Benefit cost ratio maximum is found in FYM +Azotobacter + PSB treatment and maximum net income maximum was found in Vermicompost + Azotobacter + PSB treatment.

\section{Introduction}

Strawberry (Fragariax ananassa Duch.) is one of the most delicious, refreshing and nutritious soft fruits of the world. It belongs to family Rosaceae and is native to America (Galletta et al., 1990). Strawberry is an herbaceous perennial short day plant. It was first introduced by the NBPGR Regional Research Station, Shimla (Himachal Pradesh) 
in the early sixties. Strawberry is one of the important temperate fruit of India but also being grown in sub-tropical and tropical climates. It can be grown up to 12,000 feet from mean sea level in humid and dry regions. Its successful cultivation requires an optimum day temperature of $22-23^{\circ} \mathrm{C}$ and night temperature of $7-13^{\circ} \mathrm{C}$ in India. It is excellent sources of natural antioxidants including carotenoids vitamins, phenols, flavonoids, dietary glutathionine endogenous metabolites and exhibit a high level of antioxidant capacity against free radical species (Wang and Jiao, 2000). It is cultivated to a limited extent is plains and sub mountainous areas of Himachal Pradesh, Uttarakhand, Uttar Pradesh, Maharashtra, Karnataka, Punjab, Haryana and Madhya Pradesh, wherever, irrigation facilities are available in India.

Organic substance improve Physical and chemical Soil characters, prevent soil degradation and increase beneficial important micro organisms. Organic fertilizers improved strawberries yield due to their essential elements, vitamins, enzymes and hormone. Many studies have confirmed that application of organic manure to strawberry fields improved plant nutrition and stimulate plant growth (Hargreaves et al., 2009). Uses of organic manures are environmentally safe and viable alternatives of chemical fertilizers and it increases microbial biomass in the soil (Selvamani et al., 2011). Flowering date advanced by organic matter, while it was delayed in the conventional treatment, while the highest fruit weight and total yield/plant were produced in conventional treatment (Abu-Zahra and Tahboub, 2008). Herencia et al., (2011) reported that composts contained nitrogen and phosphorus which enhanced vegetative growth and flower bud initiation. Singh et al., (2008) found significant increase in fruit yield and flowering of strawberry with vermicompost based fertilizer.
Bio-fertilizers are naturally occurring products with living microorganisms which are resulted from the roots or cultivated soil and don't have any ill effect on plants, soil health and environment. Biofertilizer viz. Azotobacter, PSB are the derived product of living microorganism that are capable to fixing atmospheric nitrogen and also convert insoluble phosphorus to soluble phosphorus for uptake of plants, and it can also increase fertility of soil and increases number and biological activities. Besides, their role in fixing atmospheric nitrogen and phosphorous solubilisation, these are also helpful in stimulating the plant growth hormones.

\section{Materials and Methods}

The present investigation was carried out at the Experimental Unit of the Department of Horticulture, TilakDhari Post Graduate College, Jaunpur, Uttar Pradesh, India during year 2017-18. Runners of strawberry $c v$. Chandler were procured from Dr. Y.S. Parmar University of Horticulture and Forestry, Nauni, (Solan), H.P. The climatic condition of Jaunpur is subtropical with three distinct seasons i.e., winter, summer and rainy. During the winter season (December-January) temperature fall, $5^{\circ} \mathrm{C}$ or even low, while in summer season (May-June) it reaches as high as $45^{\circ} \mathrm{C}$. Occasional spell of frost and precipitation may occur during winter. The mean temperature is minimum $15-20{ }^{\circ} \mathrm{C}$ and maximum 18-32 ${ }^{0} \mathrm{C}$, maximum relative humidity $95 \%$ and minimum $55 \%$ with annual rainfall of $850-1100 \mathrm{~mm}$. The strawberry runners of uniform size were transplanted 2-5 $\mathrm{cm}$ depth at a spacing of $40 \times 40 \mathrm{~cm}$. in last week of October. FYM, Vermicompost, Poultry Manure, Azotobacter and PSB were applied in the concerned plots as per the treatment. The treatments viz., $\mathrm{T}_{1}$-Control (Untreated), $\mathrm{T}_{2}$ - Farm Yard Manure, $\mathrm{T}_{3}$ Vermicompost, $\mathrm{T}_{4}$ - Poultry Manure, $\mathrm{T}_{5}$ Azotobacter, $\mathrm{T}_{6}-\mathrm{PSB}$ (Phosphorus 
Solublizing Bacteria), $\mathrm{T}_{7}-\mathrm{FYM}+$ Azotobacter + PSB, $\mathrm{T}_{8}$-Vermicompost + Azotobacter + PSB, T9-Poultry Manure + Azotobacter + PSB, $\mathrm{T}_{10}$-FYM + Vermicompost + Poultry Manure + Azotobacter + PSB were evaluated in Randomized Block Design with three replications. The required quantity of organic manures as per treatments was applied at the time of land preparation. Azotobactor, phosphorus solubilising bacteria solutions were made by dissolving $50 \mathrm{ml}+500 \mathrm{gm}$ of juggery in 20 litres of water. The roots of the strawberry runners were thoroughly dipped in the solution for about 30minutes and then planting were done. Blackpolythene of 200 gauges was used as mulch material. Other cultural practices like weeding, hoeing, irrigation, insect pest and disease management were done as and when required.

The observations were recorded on five randomly selected plants from each treatment to assess the effect of organic manures and bio-fertilizer on floral and commercial yield character in strawberry cv. chandler. Floral characters [Daysto produce first flower, number of flowers/plant, days to fruit set, number of fruit set/plant, percentage of fruit setting/plant and duration of harvesting (days)] and yield/plant (g), yield/plot (kg) and yield/ha (qt) in strawberry. The data recorded during the course of investigation were analyzed by analysis of variance (ANOVA) using the statistical program and the significance differences between the mean were tested against the critical difference at $5 \%$ probability level.

\section{Results and Discussion}

\section{Floral characters}

Mean data presented in table 1 clearly show that minimum number of days to produce first flower (50.99 days) was recorded in FYM + Vermicompost + Poultry manure +
Azotobacter+ PSB treatment with followed by Vermicompost + Azotobacter + PSB(52.99 days) alone treated plants. However, the maximum number of days to produce first flower (60.79 days) was recorded in the plants which were untreated i.e. control. These results have got the support of the findings of Kumar et al., (2015), who recorded earliest flowering with Vermicompost + PSB and Vermicompost + Azotobacter treatments in strawberry. From the table 1 it is clear that maximum number of flowers/plant (59.91) was recorded in FYM + Vermicompost + Poultry manure + Azotobacter + PSB treated plants followed by Vermicompost + Azotobacter + PSB (58.93), whereas the minimum number of flowers/plant was observed in the control (40.77). Increased number of flowers might have also resulted because of increase in number of crowns/plant. Similar observations were also reported by Tripathi et al., (2010) in strawberry, who found that higher dose of Azotobacter and PSB (7 kg/ha) increased number of flowers/plant and also Kumar et $a l .$, (2015) in strawberry.

The minimum number of days to fruit set (6.47 days) were recorded in plants treated with FYM + Vermicompost + Poultry manure + Azotobacter + PSB followed by Vermicompost + Azotobacter + PSB (6.93days), whereas, the unfertilized plants (control) took maximum days (10.99 days) for fruit setting. These results have got the support of the findings of Kumar et al., (2015), who recorded earliest flowering with Vermicompost + PSB in strawberry. From the table 1 it is obvious that number of fruit/plant (49.60) were observed maximum when the plants treated with FYM + Vermicompost+ Poultry manure Azotobacter + PSB which were significantly to Vermicompost+ Azotobacter + PSB treatment (48.68), whereas, the least number of fruit/plant (29.55) was obtained from control. Maximum 
fruit set percentage (84.05\%) was found in Vermicompost followed by $(82.79 \%)$ in FYM + Vermicompost +Poultry manure + Azotobacter + PSB, whereas, minimum fruit set percentage $(72.46 \%)$ in untreated i.e. control. However, no such reports are available from the literature and thus warrant further studies. Duration of harvesting was significantly increased with organic manure and bio-fertilizer applications. From the table 1 maximum duration of harvesting (63.75days) was observed when the plants were treated with FYM + Vermicompost + Poultry manure + Azotobacter+ PSB, followed by (62.74 days) in Vermicompost + Azotobacter + PSB treatment, whereas minimum in control (47.46 days).

Table.1 Effect of organic manure and bio-fertilizers on floral characters of strawberry cv. chandler

\begin{tabular}{|l|c|c|c|c|c|c|}
\hline Treatment & $\begin{array}{c}\text { Days to produce } \\
\text { first flower }\end{array}$ & $\begin{array}{c}\text { Number of } \\
\text { flower/plant }\end{array}$ & $\begin{array}{c}\text { Days to } \\
\text { fruit set }\end{array}$ & $\begin{array}{c}\text { Number of } \\
\text { fruit/plant }\end{array}$ & $\begin{array}{c}\text { Percentage of fruit } \\
\text { setting/plant }\end{array}$ & $\begin{array}{c}\text { Duration of } \\
\text { Harvesting } \\
\text { (days) }\end{array}$ \\
\hline $\mathbf{T}_{\mathbf{1}}$ & 60.79 & 40.77 & 10.99 & 29.55 & 72.46 & 47.46 \\
\hline $\mathbf{T}_{\mathbf{2}}$ & 55.57 & 51.71 & 8.95 & 41.57 & 80.38 & 54.61 \\
\hline $\mathbf{T}_{\mathbf{3}}$ & 53.46 & 56.42 & 7.53 & 47.42 & 84.05 & 60.48 \\
\hline $\mathbf{T}_{\mathbf{4}}$ & 58.64 & 49.23 & 9.59 & 38.02 & 77.23 & 51.88 \\
\hline $\mathbf{T}_{\mathbf{5}}$ & 59.03 & 45.19 & 9.66 & 36.44 & 80.64 & 50.61 \\
\hline $\mathbf{T}_{\mathbf{6}}$ & 59.29 & 44.27 & 9.99 & 34.75 & 78.50 & 49.67 \\
\hline $\mathbf{T}_{\mathbf{7}}$ & 54.12 & 54.61 & 8.21 & 44.48 & 81.46 & 57.51 \\
\hline $\mathbf{T}_{\mathbf{8}}$ & 52.99 & 58.93 & 6.93 & 48.68 & 82.59 & 62.74 \\
\hline $\mathbf{T}_{\mathbf{9}}$ & 55.65 & 51.44 & 9.06 & 38.61 & 75.06 & 53.09 \\
\hline $\mathbf{T}_{\mathbf{1 0}}$ & 50.99 & 59.91 & 6.47 & 49.60 & 82.79 & 63.75 \\
\hline $\mathbf{C D}$ at 5\% & 0.719 & 0.651 & 0.404 & 0.871 & 1.803 & 0.602 \\
\hline
\end{tabular}

Table.2 Effect of organic manure and bio-fertilizers on yield/plant, yield/plot and yield/ha of strawberry cv. Chandler

\begin{tabular}{|c|c|c|c|}
\hline Treatment & Yield/plant $(\mathbf{g})$ & Yield/plot $\mathbf{( k g )}$ & Yield/ha (qt) \\
\hline $\mathbf{T}_{\mathbf{1}}$ & 143.99 & 1.44 & 71.98 \\
\hline $\mathbf{T}_{\mathbf{2}}$ & 258.67 & 2.58 & 129.31 \\
\hline $\mathbf{T}_{\mathbf{3}}$ & 276.93 & 2.76 & 138.43 \\
\hline $\mathbf{T}_{\mathbf{4}}$ & 252.81 & 2.52 & 126.38 \\
\hline $\mathbf{T}_{\mathbf{5}}$ & 189.53 & 1.89 & 94.73 \\
\hline $\mathbf{T}_{\mathbf{6}}$ & 171.71 & 1.71 & 85.83 \\
\hline $\mathbf{T}_{\mathbf{7}}$ & 272.96 & 2.72 & 136.46 \\
\hline $\mathbf{T}_{\mathbf{8}}$ & 290.56 & 2.90 & 145.26 \\
\hline $\mathbf{T}_{\mathbf{9}}$ & 256.61 & 2.56 & 128.28 \\
\hline $\mathbf{T}_{\mathbf{1 0}}$ & 287.45 & 2.87 & 143.71 \\
\hline $\mathbf{C D} \mathbf{a t} \mathbf{5 \%}$ & 0.995 & 0.010 & 0.487 \\
\hline
\end{tabular}


Table.3 Economics of the different treatments per hectare in Strawberry cv. Chandler

\begin{tabular}{|c|c|c|c|c|c|c|}
\hline Treatment & $\begin{array}{c}\text { Treatment } \\
\text { cost (Rs.) }\end{array}$ & $\begin{array}{c}\text { Total cost } \\
\text { (Rs.) }\end{array}$ & $\begin{array}{c}\text { Yield/ha } \\
(\mathbf{q t})\end{array}$ & $\begin{array}{c}\text { Gross income } \\
\text { (Rs.) }\end{array}$ & $\begin{array}{c}\text { Net income } \\
\text { (Rs.) }\end{array}$ & B:C Ratio \\
\hline $\mathbf{T}_{\mathbf{1}}$ & 00000.00 & 174000.00 & 71.98 & 2159400.00 & 1985400.00 & $11.41 / 1$ \\
\hline $\mathbf{T}_{\mathbf{2}}$ & 12000.00 & 186000.00 & 129.31 & 3879300.00 & 3693300.00 & $19.85 / 1$ \\
\hline $\mathbf{T}_{\mathbf{3}}$ & 70000.00 & 244000.00 & 138.43 & 4152900.00 & 3908900.00 & $16.02 / 1$ \\
\hline $\mathbf{T}_{\mathbf{4}}$ & 10000.00 & 184000.00 & 126.38 & 3791400.00 & 3607400.00 & $19.60 / 1$ \\
\hline $\mathbf{T}_{\mathbf{5}}$ & 600.00 & 174600.00 & 94.73 & 2841900.00 & 2667300.00 & $15.27 / 1$ \\
\hline $\mathbf{T}_{\mathbf{6}}$ & 1250.00 & 175250.00 & 85.83 & 2574900.00 & 2399650.00 & $13.69 / 1$ \\
\hline $\mathbf{T}_{\mathbf{7}}$ & 13850.00 & 187850.00 & 136.46 & 4093800.00 & 3905950.00 & $20.79 / 1$ \\
\hline $\mathbf{T}_{\mathbf{8}}$ & 71850.00 & 245850.00 & 145.26 & 4357800.00 & 4111950.00 & $16.72 / 1$ \\
\hline $\mathbf{T}_{\mathbf{9}}$ & 11850.00 & 185850.00 & 128.28 & 3848400.00 & 3662550.00 & $19.70 / 1$ \\
\hline $\mathbf{T}_{\mathbf{1 0}}$ & 32517.00 & 206517.00 & 143.71 & 4311300.00 & 4104783.00 & $19.87 / 1$ \\
\hline
\end{tabular}

Similar results were also recorded by Jain et al., (2017) Tripathi et al., (2010) and Singh and Singh (2009) in strawberry, who got advanced duration of harvesting (earliness) by approximately one month which obviously extended the period of harvesting.

\section{Yield}

It was observed from the table 2 that organic manures and bio-fertilizers have given remarkable increase in the yield of strawberry fruits. The maximum yield/plant (290.56 g), yield/plot $(2.90 \mathrm{~kg})$ and yield/ha $(145.26 \mathrm{qt})$ was recorded in the plant treated Vermicompost + Azotobacter + PSB followed by yield/plant $(287.45 \mathrm{~g})$, yield/plot $(2.87 \mathrm{~kg})$ and yield/ha (143.71 qt) in FYM + Vermicompost + Poultry manure + Azotobacter + PSB fertilized plants, whereas, the minimum yield/plant (143.99 g), yield/plot $(1.44 \mathrm{~kg})$ and yield/ha $(71.98 \mathrm{qt})$ was recorded in control. These findings are in line with the Kumar et al., (2015) and Jain et al., (2017) in strawberry, who reported the capability of vermicompost and poultry manure in producing growth hormone, enzymes, antifungal and antibacterial compounds, which in turns enhanced marketable yield over other treatments.

\section{Benefit cost ratio}

Data presented the table 3 it is clear that during the investigation. The maximum benefit: cost ratio (20.79:1) was recorded from treatment FYM + Azotobacter + PSB, which was followed by treatment FYM + Vermicompost + Poultry manure + Azotobacter +PSB (19.87:1). Maximum net income was also obtained from treatment Vermicompost + Azotobacter +PSB $(41,11,950.00$ Rs.) followed by treatment FYM +Vermicompost + Poultry manure + Azotobacter+ PSB (41,04,783 Rs.). The minimum benefit: cost ratio (11.41:1) and net income $(19,85,400$ Rs.) was observed from control. Similar results were reported by Yadav et al., (2010) and Jain et al., (2017).

\section{References}

Abu-Zahra, T. R. and Tahboub, A. A. (2008). Strawberry (Fragaria $x$ anansa Dutch.) growth, flowering and yielding as affected by different organic matter sources. Intern. J. of Botany, 4 (4): 481485.

Galletta, G. J., Lawrence, F. J. and Scott, D. H. (1990). Strawberry breeding work of the United States Department $\mathrm{t}$ of Agriculture. Hort. Sci., 25: 895-896. 
Hargreaves, J. C., Adl M. S. and Warman, P. R. (2009). Are compost teas an Effective nutrient amendment in the cultivation of strawberries? Soil and plant tissue effects. J. Sci. Food Agric. 89: 390-397.

Herencia, J. F., Garcia-Galavisa, P. A., Doradoa, J. A. R. and Maqueda, C. (2011). Comparison of nutritional quality of the crops grown in an organic and conventional fertilized soil. Sci. Hort. 129(4): 882-888.

Jain, N., Mani, A., Kumari, S., Kasera, S. and Bahadur, V. (2017). Influence of INM on yield, quality, shelf life and economics of cultivation of strawberry (Fragaria xananassa Duch.) cv. Sweet Charlie. Journal of Pharmacognosy and Phytochemistry, 6 (5): 1178-1181.

Kumar, N., Singh, H. K. and Mishra, P. K. (2015). Impact of Organic Manures and Biofertilizers on Growth and Quality Parameters of Strawberry cv. Chandler. Indian Journal of Science and Technology, 8(15): 1-6.

Selvamani, P., Manivannan, K. and Jagan, M. (2011). Impact of organic manures, inorganic fertilizers and bio-fertilizers on the nutrient concentration in soil at different growth stages of banana $\mathrm{cv}$.
Poovan Mysore (Aab) (Musa pp. L.). Plant Archives, 11: 165-168.

Singh, A. and Singh, J. N. (2009). Effect of biofertilizers and bioregulators on growth, yield and nutrient status of strawberry cv. Sweet Charlie. I. J. Hort., 66: 220-224.

Singh, R., Sharma, R. R., Kumar, S., Gupta, R. and Patil, R. T. (2008). Vermicompost substitution influences the physiological disorders, fruit yield and quality of strawberry (Fragaria ananassa Duch). Bioresource Technol. 99:8507-11.

Tripathi, V. K., Kumar, N., Shukla, H. S. and Mishra, A. N. (2010). Influence of Azotobacter, Azospirillum and PSB on growth, yield and quality of strawberry cv. chandler. Abst: National Symposium on Conservation Hort., p. 198-199.

Wang, S. Y. and Jiao, H. (2000). Scavenging capacity of berry crops on superoxide radicals, hydrogen-peroxide, hydroxyl radicals, and singlet oxygen. J. Agr. Food Chem. 48: 5677-86.

Yadav, S. K., Khokhar, U. U. and Yadav, R. P. (2010). Integrated nutrient management for strawberry cultivation. Ind. J Hort. 67(4): 445-449.

\section{How to cite this article:}

Aman Srivastav, Rajaneesh Singh, Hari Baksh, Bijendra K. Singh, Raj pandey, Vishal Kumar Pal and Lawlesh Kumar Maurya. 2019. Effect of Organic Manures and Bio-Fertilizers on Floral and Commercial Yield Characters of Strawberry (Fragaria $\times$ ananassa Duch.) cv. Chandler. Int.J.Curr.Microbiol.App.Sci. 8(02): 392-397. doi: https://doi.org/10.20546/ijcmas.2019.802.044 